\title{
Tudor England Sites dedicated to the era
}

$\mathbf{T}$ his year marks the 500th anniversary of the coronation of King Henry VIII-one of England's most celebrated monarchs. In recognition of this event, this Internet Resources column is dedicated to one of the most significant periods in English history. The Tudor period (1485-1603) was a watershed in terms of politics and religion. The "Tudor Revolution" transformed the English government into an effective bureaucracy, while Henry VIII's break with Rome resulted in the establishment of the Church of England. This simultaneous transformation of government and religious thought affected every aspect of society and culture in 16th- century England. Indeed, the Tudor period ushered England out of the Middle Ages and into the Early Modern world.

The Internet boasts a wide variety of sites dedicated to the Tudor era. These sources range from general examinations of the period to primary sources more appropriate for scholarly work.

\section{Eudorfistory.org}

\section{General}

\section{overviews of the period}

- Englishhistory.net-Tudor England.

Loaded with a wealth of information on the Tudor period, this site includes detailed biographies of all the Tudor monarchs, their royal relatives, and other notable citizens of the era. Users can test their knowledge of the period in the Quizzes section. More than 20 quizzes are available on a variety of topics: from general history to the trial and execution of Anne Boleyn. The Tudor England image gallery enables users to view portraits in chronological order.
For example, portraits of Henry VIII are arranged from 1509 to 1545 . The site includes many rare portraits. Access: http:// englishhistory.net/tudor.html.

- Tudorhistory.org. This very large Web site is a wonderful place to start for anyone seeking information on the Tudor period. The homepage is comprised of links to several topics, including the Tudor monarchs, who's who in Tudor England, reference maps, and a Tudor history blog. The site offers a list of Tudor genealogical trees and a glossary of words and terms that can be browsed according to subject: architecture, law and government, or food and drink. The image gallery is quite extensive, as well. In addition to important Tudor figures, Tudor landmarks, such as Hampton Court Palace and Kenilworth Castle, are also included in the gallery. Access: http:// www.tudorhistory.org/.

\section{Notable individuals}

- Center for Thomas More Studies. Until his execution for treason in 1535, Sir Thomas More served as Henry VIII's Lord Chancellor. This Web site, maintained by the University of Dallas, promotes the study of Thomas More, "especially the contemporary implications of his principles of states-

Michele Frasier-Robinson is librarian at the Memorial Institute for the Prevention of Terrorism in Oklahoma City, e-mail: frasier@mipt.org

๑) 2009 Michele Frasier-Robinson 
manship in the pursuit of peace." A detailed biography of More is available, along with links to teacher support materials, a library, and an art gallery. The teacher support area includes the Thomas More Sourcebook, a group of study questions to accompany some of his greatest works on education, government, and religion. A download link takes users to an area allowing them to access More's History of King Richard III, as well as William Roper's Life of Sir Thomas More. The site is easy to navigate and the search tab enables users to search the entire site with the exception of the library. Access: http://www.thomasmorestudies. org/index.html.

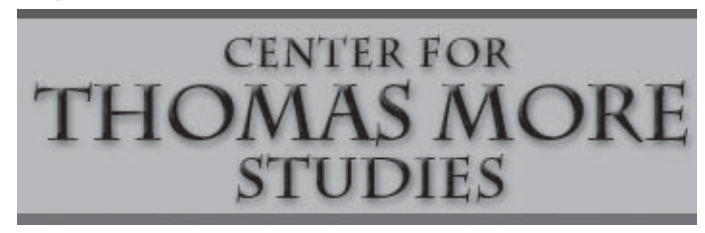

- Elizabeth I. This Web site recounts the life of perhaps the most famous female monarch in Western history. Divided into more than 30 topics, this site offers a brief biography, as well as discussions on the queen's government, pastimes, and suitors. The author addresses a long list of frequently asked questions and a lengthy list of Elizabeth's quotes is available here, as well. Access: http://elizabethi.org/.

- Mary Tudor. Dedicated to the life of Queen Mary I, this Web site chronicles her life in great detail, from her childhood years and her relationships with her siblings, to her marriage to Prince Philip of Habsburg. Also of interest are the portrait gallery and the history of La Pelegrina - the famous pearl pendant given to Mary by her Spanish husband. Access: http://home. earthlink.net/ elisale/index.html.

- The World of Mary, Queen of Scots. Although not a Tudor monarch, Mary Stuart's grandmother was a Tudor, and thus the Scottish queen plays a pivotal role in the history of the Elizabethan era. Mary's volatile relationship with her English cousin, Elizabeth I, is recounted, as are the details of her childhood and three mar- riages. Likewise, Mary's supposed involvement in treasonous plots is retold in great detail. The site contains several primary sources, including the letters Mary sent to Elizabeth during the former's imprisonment and in the days before her execution. A very helpful timeline is included and some interesting facts about Mary can be found at the "A Few Facts" link. Access: http:// www.marie-stuart.co.uk/.

\section{Literature}

- Internet Shakespeare Editions. Established by the University of Victoria, the mission of this site is to provide students, scholars, and actors access to high-quality information on William Shakespeare, his world, and his works. This site includes four major components: the foyer, the library, $\begin{aligned} & \text { Reproduced with the per- } \\ & \text { mission of the ISE. }\end{aligned}$ the theater, and the

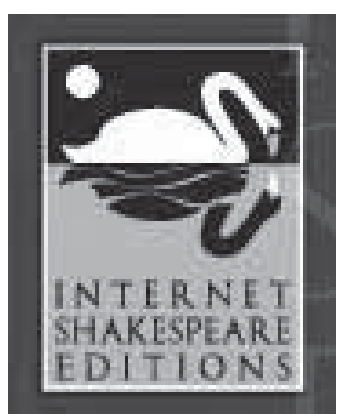
annex. The plays and poems section offers users an easily searchable database of Shakespeare's plays and poetry, from All's Well That Ends Well to Venus and Adonis. Of interest to theater students is the Shakespeare in Performance database, which contains a wealth of performance materials from hundreds of film and stage productions, including press clippings, scripts, and production notes. Access: http:// internetshakespeare.uvic.ca/index.html.

- Luminarium: Sixteenth Century Renaissance English Literature (14851603). As part of the larger, award-winning Luminarium: Antbology of English Literature, this Web site is the creation of a student who, during the dark ages of the Internet, had problems finding a centralized location for literary resources. The result is a diverse collection of writings from the likes of Henry VIII, Hugh Latimer, and father of the English sonnet, Sir Thomas Wyatt. Entries for each author include a biography and a list of works (with links 
to full-text access). Access: http://www. luminarium.org/renlit/index.html.

- The Edmund Spenser Home Page. Maintained by the English faculty at the University of Cambridge, this Web site is devoted to the study of the Elizabethan poet and author of The Faerie Queene. Full-text access to Spenser's works, including The Shepheardes Calendar and Fowre Hymnes, are included. The Edmund Spenser/Sir Philip Syndey discussion list is accessible from this site. Access: http://www.english. cam.ac.uk/spenser/main.htm.

\section{Music and culture}

- Elizabethan Costume Page. This Web site is a goldmine for anyone studying 16th-century English dress. Arranged into 15 different subject areas, this site addresses anything and everything within the realm of Elizabethan fashion. One of the most fascinating sections discusses the colors and fabrics used to make clothing this era. One article describing the types of garment dyes used in the 16th century includes recipes on how to make and prepare dyes. The site also provides information on national and regional dress, and links to historic costume suppliers. Access: http:// www.elizabethancostume.net/.

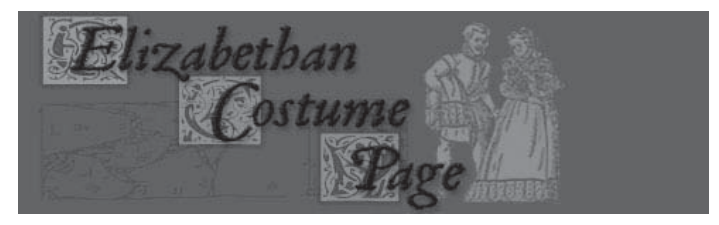

- First Book of English Madrigals. Published in 1598, this was the first of two sets of madrigals penned by composer John Wilbye. This set, with lyrics included, are for three, four, five, and six voices. Access: http://www.shipbrook.com/jeff /wilbye.html.

- Tudor Effigies. In an effort to chronicle the garments worn by men and women (especially those of the middle classes) during the 16th century, a professor at the University of Southampton has undertaken the task of photographing and analyzing effigies. The result is a wonderful database of images offering detailed information on Tudor dress. The effigy images are in chronological order from 1510 to 1604. Detailed information for each image includes the name of the deceased, a description of the monument and clothing depicted, and the geographical location of the effigy. More than 150 different effigies are represented. Access: http://www.tudoreffigies.co.uk /default.asp.

\section{Religion}

- Internet Modern History Sourcebook: English Reformation. This site offers access to a diverse list of primary sources on the English Reformation. Included are the Suppression of Glastonbury Abbey (1539) and Thomas Cranmer's Letter on Henry VIII's Divorce (1533). Users must scroll down the page to find sources for England. Access: http://www.fordham.edu /halsall/mod/modsbook02.html.

- The Tyndale Society. William Tyndale's Bible-centered approach to Christianity and his English translation of the Bible branded him as a heretic during the early Tudor period. The Tyndale Society Web site represents an organization that exists to illuminate the life and work of this English martyr. The site contains a good biography on Tyndale and descriptions of his polemical writings, including The Practice of Prelates (1530) and An Answer to Sir Thomas More's Dialogue (1531). Perhaps the best kept secret of this site is access to society news, conference proceedings, articles, and book reviews from the society's newsletter: "The Tyndale Society Journal" (click the publications link). Issues from 1995 to 2005 are available. The site offers users a search option, as well. Access: http://www.tyndale.org/.

\section{Maritime history}

- Exploration and Discovery, Elizabethan Period. The Royal Navy Web site provides access to a brief maritime history of Tudor England. Links to more information on the Spanish Armada and Sir Francis 
Drake are included. Access: http://www. royalnavy.mod.uk/server/show/nav.3843.

- The Spanish Armada. The story of Spain's attempt in 1588 to invade Elizabethan England is recounted in vivid detail here. In addition to a large map of the Spanish fleet's route, the name and firepower of each Spanish ship is listed. Likewise the name of each English ship is listed along with its commander's name. The site contains quite a bit of anecdotal information and images. Access: http://www.britishbattles.com/spanish-war /spanish-armada.htm.

\section{Primary sources}

- Calendar of State Papers, Foreign: Edward VI, Mary and Elizabeth. These 25 volumes shed light on England's relationship with the rest of Europe. Each entry is dated and the place of origin is listed. Edward and Mary are represented by one volume each, while the bulk of this collection centers on Elizabeth's reign. Nonetheless, Elizabeth's papers run through 1589 only. Each entry is dated, and the country or region of origin is listed. An index and a search feature accompany each volume. Access: http://www.british-history.ac.uk /catalogue.aspx?gid=124.

- Diary of Henry Machyn. Spanning a period of 13 years (1550-1563), this diary is a valuable source for information about daily activities in London. The author's account is filled with the descriptions of the processions and festivities that were a common occurrence in London. Machyn was in the funeral business, so it is no surprise that a great deal of his diary is devoted to the description of memorials and burials-not only those of the landed classes, but those of every social standing. Many of the author's entries detail the executions of criminals and Protestant martyrs, as well. The author also included a convenient listing of prominent officers of state for the period. Access: http://www. british-history.ac.uk/source.aspx?pubid=324.

- English Handwriting 1500-1700: An Online Course. Students or scholars about to embark on early modern manuscript transcription are sure to appreciate this paleography Web site. Developed by Cambridge University English faculty, this site includes an introduction to early modern handwriting, and examples of handwriting types used during the Tudor period. The sample transcription page is good practice for beginners. The site includes a good bibliography and other research sources. Access: http://www.english.cam. ac.uk/ceres/ehoc/.

- Letters and Papers, Foreign and Domestic, Henry VIII. This 21-volume set chronicles the domestic matters and foreign policy of Henry's 38-year reign (1509-1547). Transcribed from the original manuscripts, each volume is indexed and a search function allows the user to highlight text. This set is a who's who of Henry's reign. Not only does the user find letters from the most powerful English nobles of the period, but also those of foreign diplomats and monarchs. Access: http:// www.british-history.ac.uk/catalogue. aspx?gid= 126 .

- Two London Chronicles from the Collections of John Stow. This is a fourpart chronicle detailing events in London from 1523 to 1564 . The first three sections cover the reigns of Henry VIII, Edward VI, and Mary. Part four is very brief and covers the early years of Elizabeth's reign. An introduction and index are included. A basic and advanced search feature is available. Access: http://www.british-history.ac.uk /source.aspx?pubid=804. z

\section{C\&RL News RSS}

Cover art, article links, and other valuable information from CERL News is now available by subscribing to our RSS feed.

Point your Web browser to feeds. feedburner.com/candrlnews, and add our feed to your favorite reader, such as Bloglines or Google Reader. 